\title{
STATOLITHS AS ARCHIVES OF CEPHALOPOD LIFE CYCLE: A SEARCH FOR UNIVERSAL RULES
}

\author{
MAREK R. LIPIŃSKI \\ Department of Environmental Affairs and Tourism, Marine and Coastal Management Branch, Private Bag \\ X2, Roggebaai 8012, Cape Town, South Africa (e-mail: lipinski@mcm.wcape.gov.za)

\begin{abstract}
The role of various hard structures of fish and cephalopods as living archives is briefly reviewed, and the role of the cephalopod statolith as an archive of age is treated in more detail. The statolith deposition hypothesis is considered as a complete validation tool (in contrast to the more common partial validation). The hypothesis emphasises the role of crystallisation stabilisers (such as Sr) early on, reaction switchers (such as $\mathrm{pH}$ ) which are the deposition engines, and regulators-linkers (such as proteins) which control runaway crystallisation and are responsible for species-specific shapes and other individual details. Implications of deposition-oriented approach and research for understanding of growth and application of growth studies are also discussed.
\end{abstract}

KEY WORDS: statolith, cephalopods, life cycle, strontium

\section{INTRODUCTION}

The phylum Mollusca is diverse in a strange but simple way: it is either life in a fast lane (cephalopods) or life in a slow lane (all other molluscs). Both groups are very successful. Cephalopods have far fewer species, but some of them are extremely abundant (a situation termed "ecological success"). Most of the fast lane animals have short life spans (usually a year), and their distribution is of utmost importance for their ecological and possibly evolutionary success or failure (LIPIŃSKI 1998). Most of the slow lane molluscs live longer than a year and usually their distribution is of secondary importance for survival of subsequent generations, when compared with their age structure, reproduction, survival and growth of their offspring. This idea is dangerously close to proclaiming that "other molluscs" functionally are fish (cf. Latimeria chalumnae Smith, 1939; see PACKARD 1972: 243), which illustrates the futility of comparisons and too broad generalizations based on convergence.

Are then age and growth relatively unimportant for the ecology of cephalopods? On the contrary, age structure and growth rate affect reproductive success and survival (LIPIŃSKI et al. in prep.). Unfortunately, like in fish, age and growth of cephalopods are difficult to study and the problem is still far from satisfactory solution. In molluscs, like in fish, some hard structures (such as shells, vestigial cartilages, lenses, beaks, gladii, statoliths and, respectively, lenses, scales, vertebrae, fin rays and otoliths) are regarded as living archives of the life cycle of these animals (RHOADS \& LUTZ 1980). In this review (or scientific essay sensu SINCLAIR 1988), some aspects of this claim are critically examined. Archive is defined here as a hard or semi-hard structure which stores information in an incremental way (i.e. earliest information is stored in the oldest part of the structure). The process of storing is involuntary and should be reproducible, permanent, stable and legible. The question whether the animal may use its own archive (i.e. access the information, which, therefore, is not only a by-product of some physiological process) is not addressed in this paper. 


\section{OLD PARADIGM - NEW PARADIGM}

Since the beginning of the previous century it was firmly believed that many hard structures of marine organisms contained information about their age. Perhaps the belief followed from a parallel between concentric rings seen in transverse sections of tree trunks, and similar sections of shells and otoliths, or patterns visible on fish scales. Proof of the correspondence between the structural pattern and a given unit of time was sought in validation exercises, which were simply parallel counting, one variable being known by default. The simplest of those was the Petersen method, where the modal length progression during the real-time sampling is calculated, and structure change in hard tissues noted. This method, however, requires an assumption that migration and mixing do not take place. Another method was to put a time-mark into the scale, otolith or other structure, and count days/increments from that time-mark. Countless exercises of this type were done and published (see STEVENSON \& CAMPANA 1992). Frequently, without any critical evaluation, such data were accepted and used in population analysis, for theoretical and applied purposes.

In the $1980 \mathrm{~s}$, however, different scientific requirements for age and growth studies started to emerge. Criticism of the orthodox validation concept (RICE 1987, GAULDIE 1994) and consideration of real complex scenarios (GAULDIE et al. 1995) turned the attention of age and growth researchers to the difficulties and limitations of most of these studies. Most of the validated results were fairly accurate but imprecise. On the other hand, satisfactory precision tests were frequently taken as the proof of accuracy. Needless to say, population analysis based on uncritical and untested data was of dubious value, especially in the case of short-lived animals and when used in stock management.

At the same time, a different approach to age and growth research was proposed (GAULDIE \& NELSON 1990). This approach requires understanding of the deposition process as a validation tool and verifying the hypothesis of the circadian clock steering that process. Understandably, these studies are difficult and far from completion. However, a remarkable progress has been achieved in recent years. MUGIYA, who for a long time was the lone pioneer in this field, was joined by several teams in an effort to understand the otolith deposition process in fish (e.g. MUGIYA \& SATOH 1995).

In cephalopods, orthodox ageing procedures were applied only in the late seventies (LIPIŃSKI 1978, SPRATT 1978) and a new paradigm emerged at the same time as in fish (RADTKE 1983, LIPIŃSKI 1986).

Therefore, in cephalopods, the archive concept from the start contained parallel lines of research: orthodox, best expressed in the studies of ARKHIPKIN and co-workers (e.g. ARKHIPKIN 1993a, b, ARKHIPKIN \& NEKLUDOVA 1993, ARKHIPKIN et al. 1998), and a new paradigm, best expressed in the studies of LIPIŃSKI and co-workers (e.g. LIPIŃSKI 1993, LIPIŃSKI \& DURHOLTZ 1994, DURHOLTZ 1999). This dualism in research (Fig. 1) has already produced positive results: e.g. an explanation for the Morris' paradox (LIPIŃSKI 1993, VILLANUEVA 2000), identification and investigation of various non-incremental structures (LIPIŃSKI 1993) and most importantly, general discussion about cephalopod growth (PAULY 1998a, RODHOUSE 1998, O'DOR \& HOAR 2000, WOOD \& O'DOR 2000, LIPIŃSKI in press). Another positive result of these discussions is the establishment of the

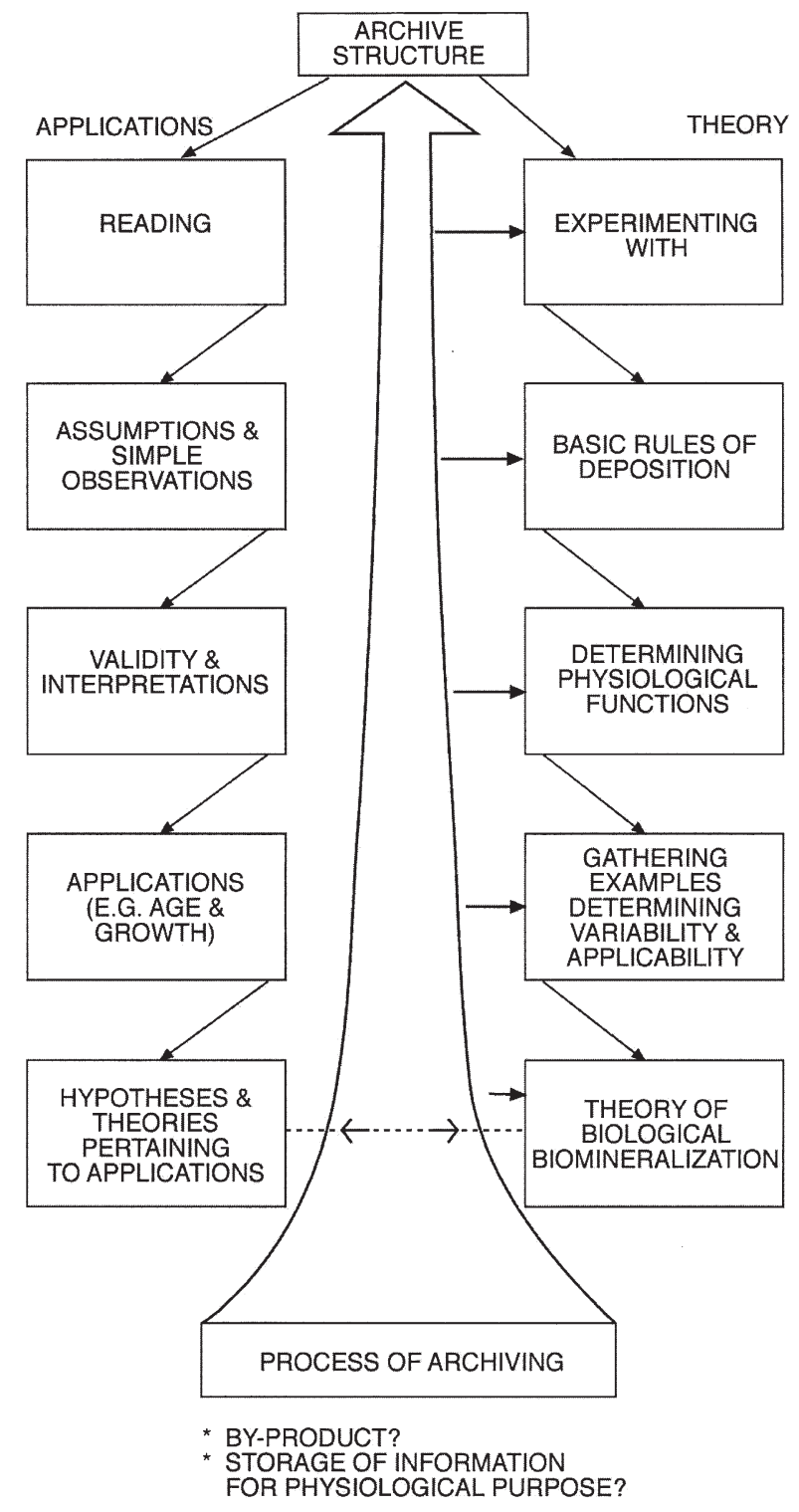

Fig. 1. Block diagram of the structure of research directed at archiving process in the hard tissues of some marine organisms 
proper context and perspective within which to view the age and growth results obtained with orthodox methods (DURHOLTZ 1999, DURHOLTZ et al. in press). The age and growth data are frequently used in the management of cephalopod resources (e.g. BRODZIAK \& MACY 1996), and in such cases the constraints of the orthodox methods (as pointed out by DURHOLTZ 1999) cannot be ignored in these pro- cedures. On the other hand, the population analysis of squid resources cannot wait for the results of physiological investigations that may take another decade to produce usable guidelines. For the sake of understanding how this particular balance was achieved in cephalopod age and growth research, a short historical review of various concepts is presented below.

\section{FIRST RESULTS AND THEIR INTERPRETATION}

Beaks, gladii, lenses and statoliths were looked at over time as potential archives of information about age, growth and environmental conditions such as temperature. Of these, statoliths investigated in the late 1950 s by the late Prof. J. Z. YOUNG (pers. comm.) as potential archives, proved to be the most valuable. Their gross morphology was first described by CLARKE (1978), mainly for systematic and evolutionary studies. Age and growth based on statoliths were first investigated by SPRATT (1978) and LIPIŃSKI (1978). Basic chemical composition was studied by RADTKE (1983), in whose paper potential use of statoliths as archives was spelt out for the first time. In 1983, LIPIŃSKI (1986) conducted the first experimental orthodox validation exercise using oxytetracycline (OTC). In the same year, similar experiments were conducted in Canada (DAWE et al. 1985). The results of validation suggested that observed and counted increments were deposited daily, but stronger conclusions could not be drawn because the size of the sample was too small. Also, observed deviations indicated a low resolution of the method of increment reading and potentially complex reasons for the deviations. Other limitations included single-species level of generalization, narrow size range and narrow time window.

LIPIŃSKI (1986) outlined the need for research of the deposition process and presented the first findings. These first simple findings may be summarized as follows:

- Growth of the statolith is unequal. This may be because of its three-dimensional shape but also because of the variable ratio of deposition in various parts. Direct injections of OTC into the statocyst result in unequal adsorption of OTC on the surface, which may indicate variable deposition ratios in various parts of the statolith. Dorsal dome, wing and rostrum display the highest adsorption.

- Definition of increments is unequal in various parts of the statoliths, and also varies between different statoliths. This may be related to various proportions between "dark" and "light" components of the increment.

- Width of increments is variable.

- Basic chemical composition is the same for various parts of the statolith, but there are quantitative differences between various parts. In particular, protein content is the highest in the wing.

- During deposition, OTC can bind to protein and not necessarily to calcium only, as maintained by earlier researchers (LIPIŃSKI 1986). Therefore, tetracycline antibiotics are not as metabolically inactive as claimed by the pharmaceutical companies at that time.

From these facts the following initial description of the deposition process was inferred. There are deposition-active proteins in some cells of macula, which are released on the wing surface (adjacent to these cells; see STEPHENS \& YOUNG 1982) and most probably into the endolymph. These proteins are the most abundant in those parts of the statolith, which are the closest to the place of their release. Therefore, their distribution in the endolymph is not uniform. They bind OTC and calcium. The amount of calcium that grows on the protein template is not proportional to the thickness of the template. Therefore, calcium crystals dominate protein-thin increments. Different definition of increments may be related to this. OTC, which is highly acid, leaves a prominent check in the statolith, but does not disrupt the deposition process.

\section{APPLIED LINE OF RESEARCH}

Some of the problems investigated include the possible improvement in increment resolution, increment interpretation, validation of readings and assess- ment of errors (see STEVENSON \& CAMPANA 1992 for definitions of these problems, and JEREB et al. 1991 for squid applications). 
Since 1980, the most popular and efficient methods of dissecting and storing statoliths were those described by LIPIŃSKI $(1980,1981)$. Dissection was done on fresh or defrosted material (formalin- or alcoholpreserved specimens seldom have their statoliths intact), by cutting through the statocyst either in a sagittal or transverse plane (orientation of the statolith according to CLARKE 1978). The statoliths were stored in $70 \%$ or $96 \%$ ethyl alcohol, or dry in plastic tubes. Cleaning in water was usually sufficient. Clearing media used were Canada Balsam, Eukitt, Euparal, liquid paraffin, and other media (LIPIŃSKI 1981, 1986, JEREB et al. 1991). First sections for light microscopy (LIPIŃSKI 1978, SPRATT 1978) were made in the transverse plane (for statolith orientation and basic definitions see CLARKE 1978 and LIPIŃSKI et al. 1991). DAWE \& NATSUKARI (1991) described the most popular methods of preparation in this plane, which were subsequently developed and published in a number of papers by ARKHIPKIN and co-workers (ARKHIPKIN 1993a, b, 1995, 1996a, b, 1997, ARKHIPKIN \& NEKLUDOVA 1993, ARKHIPKIN et al. 1998). The frontal plane preparations were first used by LIPIŃSKI (1981) and fully developed by DURHOLTZ (LIPIŃSKI \& DURHOLTZ 1994). This approach was followed by YOUNG \& MANGOLD (1994) and DAWE \& BECK (1997).

HURLEY \& BECK (1979) and KRISTENSEN (1980) were the first to use the SEM methods. LIPIŃSKI (1991) reviewed these methods, as well as chemical treatment techniques. SEM methods and frontal plane fractures or sections were originally developed for technical purposes, to investigate the structure of statoliths and ring increment, check or zone patterns, and also to find the best counting axes and/or planes. However, they were also applied to obtain total counts, not necessarily claimed to represent age in days (e.g. LIPIŃSKI et al. 1993), but used for other purposes, such as multivariate analysis of statolith dimensions and comparison between species. The transverse method for light microscopy was a routinely applied technique that assumed unambiguous daily increment recognition, and seldom considered direct validation possible and/or necessary (e.g. ARKHIPKIN 1993a, b, 1995, 1996a, b, 1997, ARKHIPKIN \& NEKLUDOVA 1993, ARKHIPKIN et al. 1998).

Sceptics (summary in CLARKE 1993 and in DURHOLTZ 1999) have rejected this approach. They argued (LIPIŃSKI \& DURHOLTZ 1994, LIPIŃSKI et al. 1998, DURHOLTZ et al. in press) that the multitude of patterns observed in the fish otolith and squid statolith indicates a very complex deposition process. Therefore, the main focus of ageing using otoliths/statoliths is to choose the correct increment pattern (e.g. best approximation of the hypothesis "one increment $=$ one day"). Full understanding of the deposition may help in the future, but at the moment many aspects of this process are only hypothetical. Therefore, direct partial validation has been recommended as the tentative way to give more weight to age and growth data (NATSUKARI et al. 1991, LIPIŃSKI \& DURHOLTZ 1994, LIPIŃSKI et al. 1998). The complete validation is so difficult that it is unrealistic to expect that it will become available soon (LIPIŃSKI et al. 1998).

In squid, many validation attempts were published, but only one of them was conducted in the natural environment (LIPIŃSKI et al. 1998). Most of these attempts strongly supported the "one increment = one day" hypothesis. However, statistically defendable support for this hypothesis has so far been impossible to obtain (LIPIŃSKI et al. 1998, DURHOLTZ 1999, DURHOLTZ et al. in press). Only two experiments concerning squid statoliths suggested that increments were not deposited daily (MORRIS 1988, VILLANUEVA 2000). The experiment conducted by MORRIS (1991, 1993) involved keeping loliginid squid embryos in their natural environment for a known number of days. Before the embryos hatched, their statoliths were taken out, increments counted and compared with the number of elapsed days. The difference between these numbers was statistically significant. To explain the results of MORRIS $(1991,1993)$, and their incompatibility with all other validation results, the existing data on the deposition process were re-analysed and new data and ideas presented (LIPIŃSKI 1993).

\section{SQUID STATOLITH DEPOSITION PROCESS}

LIPIŃSKI (1993) proposed the following hypothesis of statolith deposition, based on the fact that squid statoliths are not deposited at all when there is no strontium ( $\mathrm{Sr}$ ) in the artificial seawater (HANLON et al. 1989a). Strontium may thus be the necessary component (the building material) for the statolith structure, or it may play a regulatory role in the deposition process. However, the "regulatory role" can be usefully divided into several levels of operation, such as:
- Stabilising, where some substances (stabilisers) provide one-way direction to chemical reactions and physical processes of deposition;

- Switching, where one process is replaced by another;

- Coordinating-linking, where some substances direct a number of linked processes, or one specific process.

In the hypothesis proposed by LIPIŃSKI (1993) the main stabiliser in the deposition process is strontium; the main switch is $\mathrm{pH}$ (following MORRIS 1988) and 


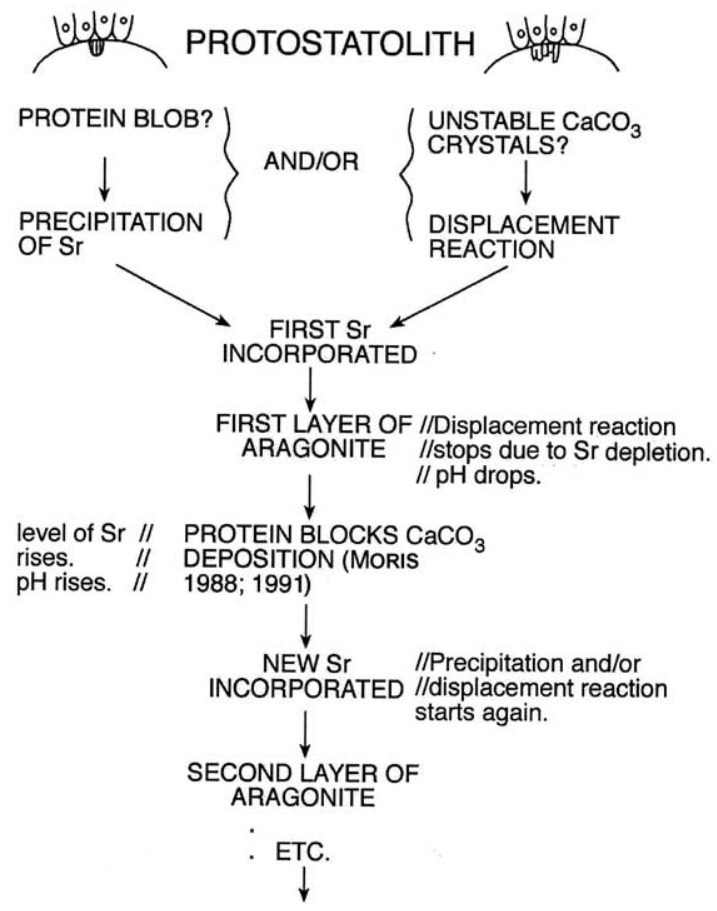

POST-HATCHING STATOLITH

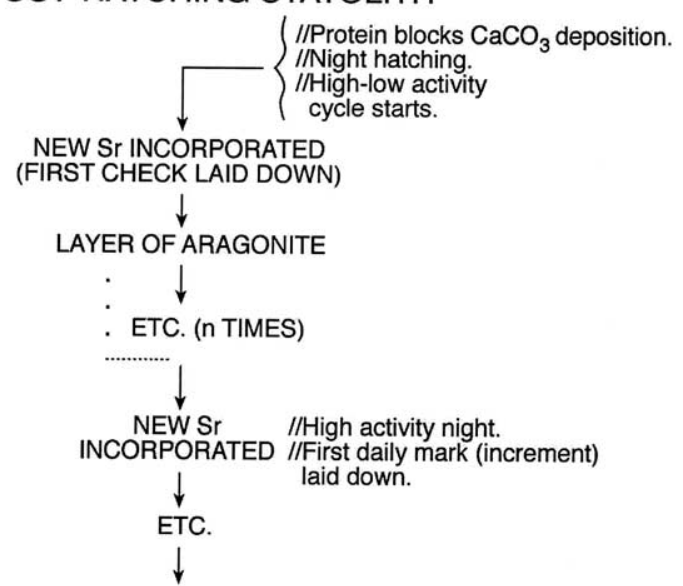

Fig. 2. The general scheme of the deposition process in the protostatolith (statolith prior to hatching) and post-hatching structure

the main coordinators-linkers are various proteins. It is assumed that $\mathrm{CaCO}_{3}$ in the form of aragonite is initially unstable in the first founding crystals of the protostatolith (LIPIŃSKI 1993). By the displacement reaction (sensu BAYER \& WIEDEMANN 1986, 1987, 1989) the stabilisation of the aragonite crystals is achieved, as well as activating the $\mathrm{pH}$ switch, which controls runaway crystallization by controlling, among other things, protein polymerisation and subsequent crystallization (Figs 2, 3). It has been further suggested that soluble matrix proteins regulate crystal growth at a molecular level, and insoluble matrix pro- teins regulate crystal growth at a morphological (incremental) level (DURHOLTZ et al. 1999).

Structural PIXE analyses provided additional arguments in favour of the proposed hypothesis (DURHOLTZ et al. 1997, LIPIŃSKI et al. 1997). However, recent results of LIPIŃSKI \& PRZYBYŁOWICZ (in prep.) suggest that the deposition process may be diverse in various groups of cephalopods. Strontium distribution in statoliths of over 20 species of squids, sepioids and octopods was vastly different. Strontium may be not only a first stabiliser, but also a stabilising component of a "dark" band of an increment (LIPIŃSKI 1993). The intensity of this process obviously may vary, which may be indicated by different strontium distributions for different species. The role of proteins may also be diverse and complex in various groups (DURHOLTZ 1999). These differences, although they may slow down research on the general rules of biomineralization, may be useful for evolutionary studies. Shapes of statoliths may be convergently similar in very diverse cephalopods (ARKHIPKIN \& BIZIKOV 2000), but the deposition process, being governed by a circadian clock, is likely to reflect true evolutionary lineages in gross structures (such as the relation of the wing to the rest of the statolith, since elemental fingerprints in otoliths are thought not to reflect genetic links; CAMPANA \& TZENG 2000). The circadian mechanism in cephalopods was not studied, but it is believed that the light/dark change acts as a "zeitgeber" (DURHOLTZ 1999). Temperature and food availability act as important enhancers or blockers/modifiers of the deposition process (DURHOLTZ \& LIPIŃSKI 2000, VILLANUEVA 2000).

What does the outlined hypothesis of the statolith deposition and its factual support contribute towards the current age and growth debate (see PAULY 1998a, b, JACKSON et al. 2000, O'DOR \& HOAR 2000, WOOD \& O'DOR 2000, LIPIŃSKI in press)?

The main contribution is providing the physiological corroboration of the increment concept. This hypothesis explains the origin of structural discontinuity in the statolith and its daily pattern. It neither explains the multitude of patterns visible in the statolith, nor does it provide the practical guidance to identify the "correct" daily pattern. However, if indeed strontium takes part only in formation of the true daily increment, induced by a day/night zeitgeber, then with the improvement of techniques of strontium identification, true daily patterns may become easily identified and counted. This line of reasoning was developed by LIPIŃSKI (1993) and supported in fish by MUGIYA \& SATOH (1995). 


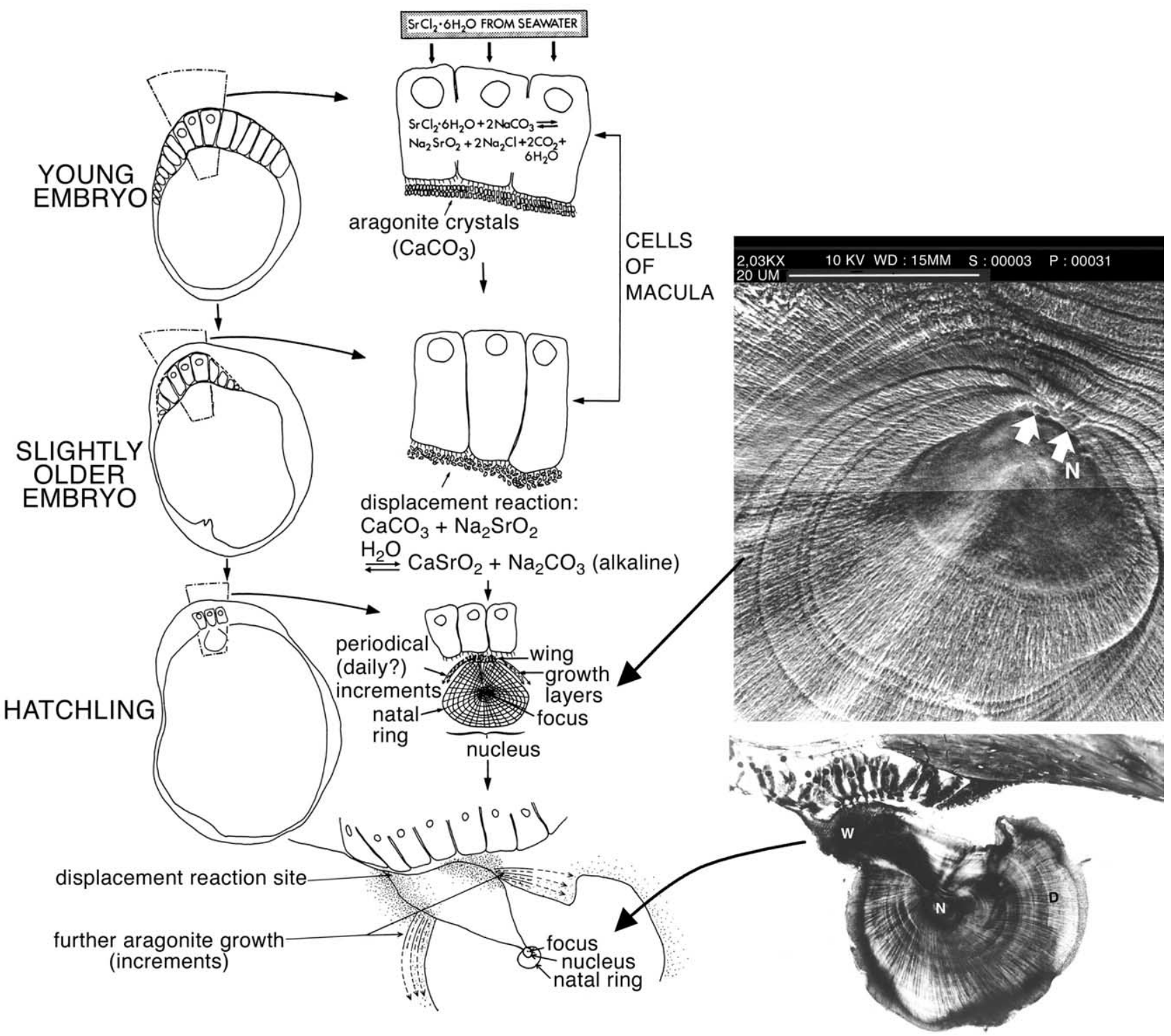

Fig. 3. The displacement reaction hypothesis of statolith deposition and accompanying evidence

\section{CEPHALOPOD GROWTH}

Recent findings (LIPIŃSKI \& PRZYBYŁOWICZ in prep.) suggest that there may be many different variants of the statolith deposition process. Does that mean that there are equally many variants of the growth patterns (if the statolith reflects the growth of the body)? There is some evidence to the contrary, as statolith growth seems to be decoupled from the growth of the organism in length, weight or shape (LIPIŃSKI et al. 1993). The statolith archive does not contain information about the growth of the body. However, there is such an archive in the gladius (BIZIKOV 1996). In fish, which follow a very different life strategy, even when their growth is quick and life short (LIPIŃSKI 1998), such a decoupling was also noted (MOSEGAARD et al. 1988; but see also LABROPOULOU \& PAPACONSTANTINOU 2000).

It seems that there are many more similarities between deposition processes in cephalopod statoliths and fish otoliths (despite large time-scale differences and possibly differences in effects) than between their respective body growth patterns and life cycle strategies. However, the latter differences were recently questioned by PAULY (1998a). He argued that physical constraints (such as physiological oxygen supply, related to $\mathrm{O}_{2}$ availability, temperature, gill size, etc.) determine the maximum size of squid and the 
tempo and mode of growth. There is, indeed, a significant positive correlation between size and longevity in cephalopods (WOOD \& O'DOR 2000), with some exceptions to that general rule (e.g. Thysanoteuthis rhombus, Sepioteuthis lessoniana and Loligo forbesi; HANLON et al. 1989b, GUERRA \& ROCHA 1994, COLLINS et al. 1995, Nigmatullin et al. 1995, PECL 2000). These exceptions suggest an explanation different from the one provided by PAULY (1998a), because his logic (i.e. "downward" deductive approach) leaves no room for exceptions. An alternative explanation may be that the species mentioned have relatively more constant access to food necessary for growth, and that their oxygen supply is adequate (see O'DOR \& HOAR 2000). Thysanoteuthis rhombus feeds almost exclusively on schools of sardine in South African waters (LIPIŃSKI, own, unpublished data), and follows these schools closely. The squid moves rather slowly, despite its very thick and muscular mantle, so it has a relatively larger body volume compared to an average neritic squid (see BLIER et al. 1997 for the argument concerning the speed of movement vs. growth).

Indeed, LIPIŃSKI \& ROELEVELD (1990) have cautioned against the "downward" approach in analysing growth functions (i.e. from the theory to its applications), because theoretical explanations for the observed fit(s) may be wrong, or the whole level of generalization may be wrong. Cephalopod growth was analysed and available ideas reviewed by LIPIŃSKI (in press). He proposed that the growth of cephalopods be described by three linear equations: the first representing slower paralarval growth, the second representing fast juvenile and adult growth, and the third representing relatively short maturation and spawning "growth" (or its lack).

\section{REFERENCES}

ARKHIPKIN A. [I.] 1993a. Age, growth, stock structure and migratory rate of prespawning short-finned squid Illex argentinus based on statolith ageing investigations. Fisheries Res. 16: 313-338.

ARKHIPKIN A. [I.] 1993b. Statolith microstructure and maximum age of Loligo gahi (Myopsida: Loliginidae) on the Patagonian shelf. J. mar. biol. Assoc. U. K. 73: 979-982.

ARKHIPKIN A. I. 1995. Statolith microstructure and maximum age of the sepiolid Rossia pacifica (Cephalopoda, Sepioidea) in the northern part of the North Pacific. Sarsia 80: 237-240.

ARKHIPKIN A. [I.] 1996a. Geographical variation in growth and maturation of the squid Illex coindetii (Oegopsida, Ommastrephidae) off the North-West African coast. J. mar. biol. Assoc. U. K. 76: 1091-1106.

ARKHIPKIN A. [I.] 1996b. Age and growth of planktonic squids Cranchia scabra and Liocranchia reinhardti (Cephalopoda, Cranchiidae) in epipelagic waters of the central-east Atlantic. J. Plankt. Res. 18: 1675-1683.

ARKHIPKIN A. I. 1997. Age and growth of the mesopelagic squid Ancistrocheirus lesueurii (Oegopsida: Ancistrocheiridae) from the central-east Atlantic based on statolith microstructure. Mar. Biol. 129: 103-111.

ARKHIPKIN A. I., BIZIKOV V. A. 2000. Role of the statolith in functioning of the acceleration receptor system in squids and sepioids. J. Zool. Lond. 250: 31-55.

ARKhipkin A. I., BIZIKOV V. A., VerkhunOV A. V. 1998. Distribution and growth in juveniles of the squid Berryteuthis magister (Cephalopoda, Gonatidae) in the western Bering Sea. Sarsia 83: 45-54.

ARKHIPKIN A. [I.], NeKLUdOvA N. 1993. Age, growth and maturation of the loliginid squids Alloteuthis africana and A. subulata on the west African shelf. J. mar. biol. Assoc. U. K. 73: 949-961.

BAYER G., WiEDEMANN H. G. 1986. Displacement reactions in gypsum. I. Thermochim. Acta 103: 247-257.

BAYER G., WiedemanN H. G. 1987. Displacement reactions in gypsum and in anhydrite. Thermochim. Acta 114: 75-82.

BAYER G., WiEDEMANN H. G. 1989. Kinetics of formation of $\mathrm{CaWO}_{4}$ and $\mathrm{CaMoO}_{4}$ from calcium carbonates and sulphates. Int. Lab. 19: 26-33.

BIZIKOV V. A. 1996. Atlas of morphology and anatomy of the gladius of squids. Izd. VNIRO, Moskva [In Russian].

BLIER P. U., PELLETIER D., DUTIL J.-D. 1997. Does aerobic capacity set a limit on fish growth rate? Rev. Fish. Sci. 5: 323-340.

BRODZIAK J. K., MACY III W. K. 1996. Growth of long-finned squid, Loligo pealei, in the northwest Atlantic. Fish. Bull. USA 94: 212-236.

CAMPANA S. E., TZENG W.-N. 2000. Section 4: Otolith composition (editorial). In: $2^{\text {nd }}$ International Symposium on Fish Otolith Research \& Application, Bergen, Norway, 20-25 June 1998 (Fossum P., Kalish J., Moksness E., eds), pp. 287-288, Fisheries Res. Spec. Issue 46, Elsevier, Amsterdam.

CLARKE M. R. 1978. The cephalopod statolith - an introduction to its form. J. mar. biol. Assoc. U. K. 58: 701-712.

CLARKE M. R. 1993. Age determination and common sensea free discussion on difficulties encountered by the author. In: Recent advances in cephalopod fisheries biology (OKUTANi T., O'DOR R. K., KUBODERA T., eds), pp. 670-678, Tokai University Press, Tokyo.

Collins M. A., Burnell G. M., Rodhouse P. G. 1995. Age and growth of the squid Loligo forbesi (Cephalopoda: Loliginidae) in Irish waters. J. mar. biol. Assoc. U. K. 75: 605-620.

DAWE E. G., BECK P. C. 1997. Population structure, growth, and sexual maturation of short-finned squid (Illex illecebrosus) at Newfoundland. Can. J. Fish. Aquat. Sci. 54: 137-146. 
DAWE E. G., NATSUKARI Y. 1991. Light microscopy. In: Squid age determination using statoliths. Section 2. Practical procedures of squid ageing using statoliths. A laboratory manual (JEREB P., RAGONESE S., VON BOLETZKY S., eds), pp. 83-95, NTR-ITPP Special Publication 1, Carlo Lauricella Stampa, Palermo, Italy.

DAWE E. G., O’DOR R K., OdENSE P. H., HuRley G. V. 1985. Validation and application of an ageing technique for short-finned squid (Illex illecebrosus). J. Northw. Atl. Fish. Sci. 6: 107-116.

DURHOLTZ M. D. 1999. Biomineralization in loliginid squid statocysts and the use of statoliths to estimate age. Ph.D. Thesis, Department of Zoology, University of Cape Town, South Africa.

DuRholtz M. D., KRETSINGER R. H., LiPIŃSKI M. R. 1999. Unique proteins from the statoliths of Lolliguncula brevis (Cephalopoda: Loliginidae). Comp. Biochem. Physiol. B 123: 381-388.

DURHOLTZ M. D., LIPIŃSKI M. R. 2000. Influence of temperature on the microstructure of statoliths of the thumbstall squid Lolliguncula brevis. Mar. Biol. 136: 1029-1037.

Durholtz M. D., LiPiŃski M. R., PRZYBYŁOWicz W. J., MESJASZ-PRZYBYŁOWICZ J. 1997. Nuclear microprobe mapping of statoliths of chokka squid Loligo vulgaris reynaudii d'Orbigny, 1845. Biol. Bull. (Woods Hole) 193: 125-140.

Durholtz M. D., LIPIŃSKI M. R., FIELD J. G. in press. Validation of daily increments in the statoliths of the South African chokka squid Loligo vulgaris reynaudii: a re-evaluation. J. Exp. Mar. Biol. Ecol.

GAULDIE R. W. 1994. The morphological basis of fish age estimation methods based on the otolith of Nemadactylus macropterus. Can. J. Fish. Aquat. Sci. 51: 2341-2362.

Gauldie R. W., Nelson D. G. A. 1990. Otolith growth in fishes. Comp. Biochem. Physiol. A 97: 119-135.

GAUldie R. W., WEST I. F., COOTE G. E. 1995. Evaluating otolith age estimates for Hoplostethus atlanticus by comparing patterns of checks, cycles in microincrement width, and cycles in strontium and calcium composition. Bull. Mar. Sci. 56: 76-102.

GUERRA A., ROCHA F. 1994. The life history of Loligo vulgaris and Loligo forbesi (Cephalopoda: Loliginidae) in Galician waters (NW Spain). Fish. Res. U. K. 21: 43-69.

HANLON R. T, BIDWELl J. P., TAIT R. 1989a. Strontium is required for statolith development and thus normal swimming behaviour of hatchling cephalopods. J. exp. Biol. 141: 187-195.

HANLON R. T., YANG W. T., TURK P. E., LEE P. G., HiXON R. F. 1989b. Laboratory culture and estimated life span of the Eastern Atlantic squid, Loligo forbesi Steenstrup, 1856 (Mollusca: Cephalopoda). Aquat. Fish. Manag. 20: $15-34$.

HURLEY G. V., BECK P. 1979. The observation of growth rings in statoliths from the ommastrephid squid, Illex illecebrosus. Bull. Am. Malacol. Union Inc. 1979: 23-29.

Jackson G. D., Alford R. A., ChOAT J. H. 2000. Can length frequency analysis be used to determine squid growth? An assessment of ELEFAN. ICES J. Mar. Sci. 57: 948-954.

JEREB P., RAgONESE S., VON BOlEtZKY S. (eds) 1991. Squid age determination using statoliths. NTR-ITPP Special
Publication No. 1, Carlo Lauricella Stampa, Palermo, Italy.

KRISTENSEN T. K. 1980. Periodical growth rings in cephalopod statoliths. Dana 1: 39-51.

LABRopopoulu M., PAPACONSTANTINOU C. 2000. Comparison of otolith growth and somatic growth in two macrourid fishes. Fish. Res. U. K. 46: 177-188.

LIPIŃSKI M. R. 1978. The age of squids, Illex illecebrosus (Lesueur, 1821), from their statoliths. Int. Commn NW Atl. Fish. Res. Doc. 78/II/15 (5167): 1-4.

LIPIŃSKI M. R. 1980. A preliminary study on ageing of squids from their statoliths. NW Atl. Fish. Org. SCR Doc. 80/II/22 (N054, revised): 1-12.

LIPIŃSKI M. R. 1981. Statoliths as a possible tool for squid age determination. Bull. l'Acad. Pol. Sci. (Cl. II, sci. biol.) 28: 569-582.

LIPIŃSKI M. [R.] 1986. Methods for the validation of squid age from statoliths. J. mar. biol. Assoc. U. K. 66: 505-526.

LIPIŃSKI M. [R.] 1991. Practical procedures of squid ageing using statoliths. A laboratory manual. Scanning Electron Microscopy (SEM) and chemical treatment. In: Squid age determination using statoliths (JEREB P., RAGONESE S., VON BOLETZKY S., eds), pp. 97-112 \& 119-124 (references), NTR-ITPP Special Publication No. 1, Carlo Lauricella Stampa, Palermo, Italy.

LIPIŃSKI M. R. 1993. The deposition of statoliths: a working hypothesis. In: Recent Advances in Cephalopod Fisheries Biology (OKUTANI T., O'DOR R. K., KUBODERA T., eds), pp. 241-262, Tokai University Press, Tokyo.

LIPIŃSKI M. R. 1998. Cephalopod life cycles: patterns and exceptions. S. Afr. J. mar. Sci. 20: 439-447.

LIPIŃSKI M. R. in press (2002). Growth of cephalopods. Proc. Vth Int. Symp. Cephalopods - Present and Past (Summesberger H., Histon K., eds). Abhandl. Geol. Bundes. 57.

LIPIŃSKI M. [R.], DAWE E., NATSUKARI Y. 1991. Practical procedures of squid ageing using statoliths. A laboratory manual. Introduction. In: Squid age determination using statoliths (JEREB P., RAGONESE S., VON BOLETZKY S., eds), pp. 77-81 \& 119-124 (references), NTR-ITPP Special Publication No. 1, Carlo Lauricella Stampa, Palermo, Italy.

LIPIŃSKI M. R., DURHOLTZ M. D. 1994. Problems associated with ageing squid from their statoliths: towards a more structured approach. Antarct. Sci. 6: 215-222.

LIPIŃSKI M. R., DURhOLTZ M. D, UNDERHILl L. G. 1998. Field validation of age readings from the statoliths of chokka squid (Loligo vulgaris reynaudii d'Orbigny, 1845) and an assessment of associated errors. ICES J. mar. Sci. 55: 240-257.

LIPIŃSKI M. R., PRZYBYŁOWICZ W. J. in prep. Elemental composition of statoliths of diverse cephalopod species. Biol. Bull. (Woods Hole).

LipiŃski M. R., PrzYBYŁowicz W. J., Durholtz M. D., MESJASZ-PRZYBYŁOWICZ J. 1997. Quantitative micro-PIXE mapping of squid statoliths. Nucl. Instr. Meth. Phys. Res. B 130: 374-380.

LIPIŃSKI M. R., ROELEVELD M. A. C. 1990. Minor extension of the von Bertalanffy growth theory. Fish. Res. U. K. 9: 367-371. 
LIPIŃSKI M. R., ROELEVEld M. A. C., UNDERHILl L. G. 1993. Comparison of the statoliths of Todaropsis eblanae and Todarodes angolensis (Cephalopoda: Ommastrephidae) in South African waters. In: Recent advances in cephalopod fisheries biology (OKUTANI T., O’DOR R. K., KUBODERA T., eds), pp. 263-273, Tokai University Press, Tokyo.

LipiŃSki M. R., Wissel C., NAVARro R., D’Oliveira J. In prep. A model of loliginid squid survival (Cephalopoda: Loliginidae).

MORRIS C. C. 1988. Statolith growth lines and statolith function in the Cephalopoda. Ph.D. Thesis, University of Cambridge, U. K.

MORRIS C. C. 1991. Statocyst fluid composition and its effects on calcium carbonate precipitation in the squid Alloteuthis subulata (Lamarck, 1798): towards a model for biomineralization. Bull. Mar. Sci. 49: 379-388.

MORRIS C. C. 1993. Environmental effects on increment formation in embryonic statoliths of the squid Alloteuthis subulata (Myopsida: Loliginidae). J. Ceph. Biol. 2: 23-32.

MosegaArd H., SvedAng H., TABerman K. 1988. Uncoupling of somatic and otolith growth rates in Arctic char (Salvelinus alpinus) as an effect of differences in temperature response. Can. J. Fish. Aquat. Sci. 45: 1514-1524.

MugrYA Y., SATOH C. 1995. Strontium-calcium ratios change corresponding to microincrements in otoliths of the goldfish Carassius auratus. Fish. Sci. Japan 61: 361-362.

NATSUKARI Y., DAWE E., LIPIŃSKI M. [R.] 1991. Practical procedures of squid ageing using statoliths. A laboratory manual. Interpretation of data. In: Squid age determination using statoliths (JEREB P., RAGONESE S., VON BOLETZKY S., eds), pp. 113-116 \& 119-124 (references), NTR-ITPP Special Publication No. 1, Carlo Lauricella Stampa, Palermo, Italy.

Nigmatullin C. M., ARKhipkin A. I., SABiROV Y. R. 1995. Age, growth and reproductive biology of diamondshaped squid Thysanoteuthis rhombus (Oegopsida: Thysanoteuthidae). Mar. Ecol. Prog. Ser. 124: 73-87.

O’DOR R. K., HOAR J. A. 2000. Does geometry limit squid growth? ICES J. mar. Sci. 57: 8-14.

PACKARD A. 1972. Cephalopods and fish: limits of convergence. Biol. Rev. 47: 241-307.

PAULY D. 1998a. Why squid, though not fish, may be better understood by pretending they are. S. Afr. J. mar. Sci. 20: $47-58$.
PAULY D. 1998b. Tropical fishes: patterns and propensities. J. Fish Biol. 53 (Supplement A): 1-17.

PECL G. T. 2000. Comparative life history of tropical and temperate Sepioteuthis squids in Australian waters. Ph.D. Thesis, School of Marine Biology and Aquaculture, James Cook University, Townsville, Australia.

RADTKE R. L. 1983. Chemical and structural characteristics of statoliths from the short-finned squid Illex illecebrosus. Mar. Biol. 76: 47-54.

RHOADS D. C., LUTZ R. A (Eds) 1980. Skeletal growth of aquatic organisms. Biological records of environmental change. Plenum Press, New York and London.

RICE J. A. 1987. Reliability of age and growth-rate estimates derived from otolith analysis. In: Age and growth of fish (Summerfelt R. C., Hall G. E., eds), pp. 167-176, The Iowa State University Press, Ames, Iowa, USA.

RODHOUSE P. G. 1998. Physiological progenesis in cephalopod Molluscs. Biol. Bull. (Woods Hole) 195: 17-20.

SINCLAIR M. 1988. Marine populations: An essay on population regulation and speciation. Washington Sea Grant/Univ. Washington Press, Seattle.

SPRATT J. D. 1978. Age and growth of the market squid, Loligo opalescens Berry, in Monterey Bay. Fish Bull. Calif. USA 169: 35-44.

STEPHENS P. R., YOUNG J. Z. 1982. The statocyst of the squid Loligo. J. Zool. Lond. 197: 241-266.

Stevenson D. K., CAMPAnA S. E. (Eds) 1992. Otolith microstructure examination and analysis. Can. Spec. Publ. Fish. Aquat. Sci. 117, Dept. Fish. Oceans, Ottawa.

VILLANUEVA R. 2000. Differential increment-deposition rate in embryonic statoliths of the loliginid squid Loligo vulgaris. Mar. Biol. 137: 161-168.

WOOD J. B., O’DOR R. K. 2000. Do larger cephalopods live longer? Effects of temperature and phylogeny on interspecific comparisons of age and size at maturity. Mar. Biol. 136: 91-99.

YOUNG R. E., MANGOLD K. M. 1994. Growth and reproduction in the mesopelagic-boundary squid Abralia trigonura. Mar. Biol. 119: 413-421.

reveived: September 1st, 2001

accepted: October 1st, 2001 